\title{
Breakdown Characteristics of C3F7CN/CO2 Gas Mixtures in Rod-Plane Gaps
}

DOI:

10.1109/ICHVE.2018.8641943

\section{Document Version}

Final published version

Link to publication record in Manchester Research Explorer

\section{Citation for published version (APA):}

Loizou, L., Chen, T., \& Liu, Q. (2019). Breakdown Characteristics of C3F7CN/CO2 Gas Mixtures in Rod-Plane Gaps. In 2018 International Conference on High Voltage Engineering and Application, Athens, Greece, September 10-13, 2018 https://doi.org/10.1109/ICHVE.2018.8641943

\section{Published in:}

2018 International Conference on High Voltage Engineering and Application, Athens, Greece, September 10-13, 2018

\section{Citing this paper}

Please note that where the full-text provided on Manchester Research Explorer is the Author Accepted Manuscript or Proof version this may differ from the final Published version. If citing, it is advised that you check and use the publisher's definitive version.

\section{General rights}

Copyright and moral rights for the publications made accessible in the Research Explorer are retained by the authors and/or other copyright owners and it is a condition of accessing publications that users recognise and abide by the legal requirements associated with these rights.

\section{Takedown policy}

If you believe that this document breaches copyright please refer to the University of Manchester's Takedown Procedures [http://man.ac.uk/04Y6Bo] or contact uml.scholarlycommunications@manchester.ac.uk providing relevant details, so we can investigate your claim.

\section{OPEN ACCESS}




\title{
Breakdown Characteristics of $\mathrm{C}_{3} \mathrm{~F}_{7} \mathrm{CN} / \mathrm{CO}_{2}$ Gas Mixtures in Rod-Plane Gaps
}

\author{
L. Loizou*, L. Chen and Q. Liu \\ School of Electrical and Electronic Engineering \\ The University of Manchester \\ Manchester M13 9PL, UK \\ *loizos.loizou@manchester.ac.uk
}

\begin{abstract}
Sulphur hexafluoride $\left(\mathrm{SF}_{6}\right)$ is an excellent dielectric medium that has been extensively used in gas insulated high voltage equipment. However, due to its high environmental impact, it is increasingly important to find an environmentally friendly alternative to $\mathrm{SF}_{6}$ in the electrical industry. $\mathrm{C}_{3} \mathrm{~F}_{7} \mathrm{CN}$, which shares similar physical and chemical properties as $\mathrm{SF}_{6}$, is considered to be a viable candidate for applications in gas insulated equipment. The high boiling point of $\mathrm{C}_{3} \mathrm{~F}_{7} \mathrm{CN}$ indicates that it has to be used as part of a mixture with a buffer gas such as $\mathrm{CO}_{2}$. This paper provides an overview on the breakdown performance of $\mathrm{C}_{3} \mathrm{~F}_{7} \mathrm{CN} / \mathrm{CO}_{2}$ mixtures in non-uniform field. Tests were carried out on $\mathrm{C}_{3} \mathrm{~F}_{7} \mathrm{CN} / \mathrm{CO}_{2}$ mixtures using a rod-plane electrode and subjected to standard lightning impulse $(1.2 / 50 \mu \mathrm{s})$ The $50 \%$ breakdown voltage, $U_{50}$, and $V$-t characteristics were obtained for $\mathrm{C}_{3} \mathrm{~F}_{7} \mathrm{CN}$ mixtures. Results have demonstrated that increased $\mathrm{C}_{3} \mathrm{~F}_{7} \mathrm{CN}$ concentrations in the mixture as well as longer electrode gap spacing can increase the breakdown strength of the test gas mixtures. A mixture of $20 \% \mathrm{C}_{3} \mathrm{~F}_{7} \mathrm{CN} / 80 \% \mathrm{CO}_{2}$ has shown higher breakdown strength than $\mathrm{SF}_{6}$ in non-uniform field.
\end{abstract}

\section{INTRODUCTION}

Sulphur hexafluoride $\left(\mathrm{SF}_{6}\right)$ is widely used as an insulation and an interruption medium for applications such as gas insulated lines and switchgear. Approximately 10,000 tons of $\mathrm{SF}_{6}$ are being installed annually [1]. The combination of several key properties such as high dielectric strength, good arc quenching capability, low boiling point as well as being chemically inert, non-toxic and non-flammable make it an almost ideal dielectric for high voltage equipment. However, with a global warming potential (GWP) 23,500 [2] times higher than that of $\mathrm{CO}_{2}$ and an estimated atmospheric lifetime of 3,200 years, $\mathrm{SF}_{6}$ is considered to be a highly potent greenhouse gas. For this reason, there is an increasing interest from both industries and academics to find a suitable replacement gas with a much lower environmental impact.

Research in $\mathrm{SF}_{6}$ alternatives has been ongoing for decades and gases such as perfluorocarbons, perfluoroketones and many others have been investigated. However, the task of replacing $\mathrm{SF}_{6}$ has proven to be challenging as it is difficult to find an ideal substitute that combines all the key properties of $\mathrm{SF}_{6}$. Two well-known emerging candidates for replacing $\mathrm{SF}_{6}$ are Novec ${ }^{\mathrm{TM}} 4710\left(\mathrm{C}_{3} \mathrm{~F}_{7} \mathrm{CN}\right)[3]$ and Novec ${ }^{\mathrm{TM}} 5110\left(\mathrm{C}_{5} \mathrm{~F}_{10} \mathrm{O}\right)$ [4]. The high boiling point of $\mathrm{C}_{5} \mathrm{~F}_{10} \mathrm{O}\left(27^{\circ} \mathrm{C}\right)$ means that it may be difficult to find a $\mathrm{C}_{5} \mathrm{~F}_{10} \mathrm{O}$ mixture with comparable dielectric strength to $\mathrm{SF}_{6}$ whilst maintaining its gaseous form in compressed gas insulated equipment. As a result, $\mathrm{C}_{3} \mathrm{~F}_{7} \mathrm{CN}$ is considered to be a more technically viable solution, especially in high voltage equipment.

This paper investigates the breakdown characteristics of $\mathrm{C}_{3} \mathrm{~F}_{7} \mathrm{CN}$ in terms of mix ratios and electrode gap distances. The obtained data were then compared to $\mathrm{SF}_{6}$ data acquired from the literature [5]. V-t characteristics of $\mathrm{C}_{3} \mathrm{~F}_{7} \mathrm{CN}$ mixtures were also examined for different gas concentrations and electrode gap distances.

\section{COMPARISON OF $\mathrm{SF}_{6} \mathrm{AND}_{3} \mathrm{C}_{7} \mathrm{CN}$ GASES}

$\mathrm{C}_{3} \mathrm{~F}_{7} \mathrm{CN}$, also known as Novec ${ }^{\mathrm{TM}} 4710$ or 2,3,3,3-tetrafluoro2-(trifluoromethyl)propanenitrile [ $\left.\left(\mathrm{CF}_{3}\right)_{2} \mathrm{CFCN}\right]$, belongs to the fluoronitriles group. $\mathrm{C}_{3} \mathrm{~F}_{7} \mathrm{CN}$ has several similar properties to $\mathrm{SF}_{6}$ [3]. Both gases are non-flammable, odourless, colourless and non-ozone depleting.

Table I compares the basic properties of $\mathrm{SF}_{6}$ and $\mathrm{C}_{3} \mathrm{~F}_{7} \mathrm{CN}$. It is noteworthy that the GWP of $\mathrm{C}_{3} \mathrm{~F}_{7} \mathrm{CN}$ is still reasonably high at 2,100 . However, only $4-10 \% \mathrm{C}_{3} \mathrm{~F}_{7} \mathrm{CN}$ is used in the mixture for existing commercial products, which represents a $98 \%$ reduction in GWP when compared to $\mathrm{SF}_{6}$ [1]. The other key difference between the two gases lies in the atmospheric lifetime. While $\mathrm{C}_{3} \mathrm{~F}_{7} \mathrm{CN}$ can decompose within 30 years, $\mathrm{SF}_{6}$, due to its long atmospheric lifetime, has an accumulative environmental impact over time.

$\mathrm{C}_{3} \mathrm{~F}_{7} \mathrm{CN}$ has inherently high dielectric strength. In its pure form, the dielectric strength of $\mathrm{C}_{3} \mathrm{~F}_{7} \mathrm{CN}$ is approximately double than that of $\mathrm{SF}_{6}$. However, given the fact that it has a relatively high boiling point $\left(-4.7^{\circ} \mathrm{C}\right)$, it has to be used in low concentrations as part of a binary mixture with a diluent gas such as $\mathrm{CO}_{2}$ or $\mathrm{N}_{2}$. The literature [3] articulates that $\mathrm{C}_{3} \mathrm{~F}_{7} \mathrm{CN} / \mathrm{CO}_{2}$ mixtures have comparably higher breakdown strength than their $\mathrm{C}_{3} \mathrm{~F}_{7} \mathrm{CN} / \mathrm{N}_{2}$ counterpart. Therefore, this paper focuses the investigation on $\mathrm{C}_{3} \mathrm{~F}_{7} \mathrm{CN} / \mathrm{CO}_{2}$ mixtures.

TABLE I

COMPARISON OF PROPERTIES FOR $\mathrm{C}_{3} \mathrm{~F}_{7} \mathrm{CN} \mathrm{AND} \mathrm{SF}_{6}[2][3]$

\begin{tabular}{lcc}
\hline \hline Property (at $\left.\mathbf{2 5}^{\circ} \mathbf{C}\right)$ & $\mathbf{C}_{\mathbf{3}} \mathbf{F}_{\mathbf{7}} \mathbf{C N}$ & $\mathbf{S F}_{\mathbf{6}}$ \\
\hline Molecular Weight (g/mol) & 195 & 146 \\
Boiling Point $\left({ }^{\circ} \mathbf{C}\right)$ & -4.7 & -63.8 \\
Vapour Pressure [bar (g)] & 1.5 & 20.5 \\
Dielectric Strength at 0 bar (g) [pu to $\left.\mathbf{S F}_{\mathbf{6}}\right]$ & $\approx 2$ & 1 \\
Atmospheric Lifetime (years) & 30 & 3,200 \\
Global Warming Potential (GWP) & 2,100 & 23,500 \\
\hline \hline
\end{tabular}




\section{EXPERIMENTAL SETUP AND PROCEDURE}

\section{A. Experimental Setup}

A small poly (methyl methacrylate) (PMMA) pressure chamber was fabricated. The pressure chamber was first vacuumed, then filled with the designated gas mixture up to atmospheric pressure ( 1 bar absolute) and was allowed to settle for an hour prior to testing. The experimental test circuit is shown in Fig. 1.

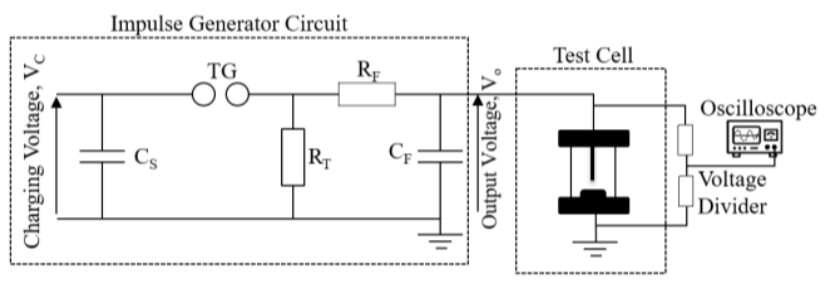

Figure 1. Lightning impulse generator test circuit.

All electrodes were made of brass alloy which is compatible with $\mathrm{C}_{3} \mathrm{~F}_{7} \mathrm{CN}$. Rod-plane electrode configuration was used to represent a non-uniform field distribution. The rod electrode tip had a $35^{\circ}$ angle while the plane was a Rogowski profile electrode. The electrode gap distance, g, can be adjusted externally from 10 to $30 \mathrm{~mm}$ using an adjustable handle on the high voltage electrode side. The lower electrode is always in a fixed position. Prior to a set of experiments, electrodes were firstly polished and then cleaned with acetone to clear the flashover marks from the previous tests. The test cell and electrode dimensions are shown in Fig. 2.
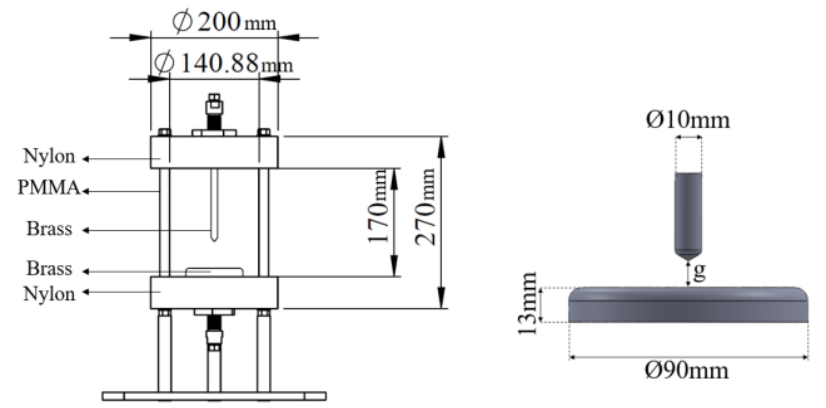

Figure 2. Dimensions of pressure vessel and test electrodes.

\section{B. Experimental Procedure}

A standard lightning impulse voltage waveform $(1.2 / 50 \mu \mathrm{s})$ was applied to the high voltage electrode of the test cell. The up-and-down procedure was carried out following the guidance of the BS EN 60060-1:2010 standard [7]. Fig. 3 shows a typical set of tests following the up-and-down procedure. For every test arrangement, a set of 40 impulses was used to determine the $50 \%$ breakdown voltage, $\mathrm{U}_{50}$, of the gas mixture. Everytime a gas mixture was refilled, it was observed that the breakdown voltage was rising with the number of impulse applications before reaching a stable up-and-down procedure. This is described in [8] as the conditioning effect, where particles can initiate breakdowns at lower voltages but are later reduced in size and affect the breakdown voltage less. This

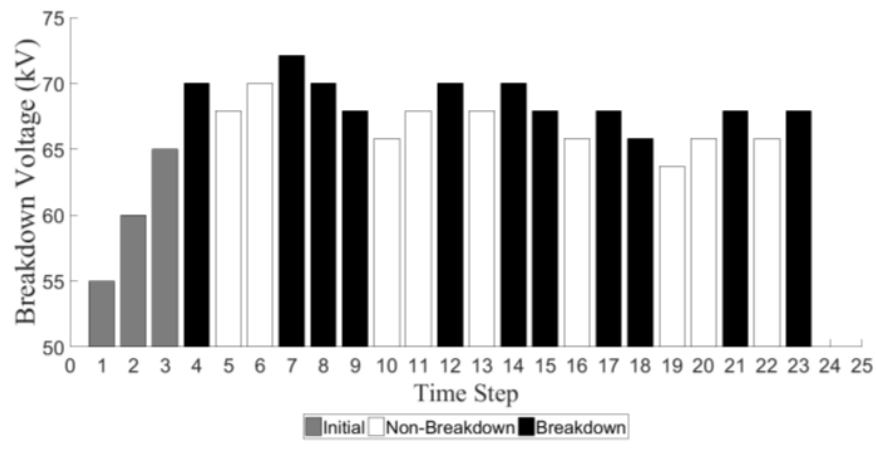

Figure 3. Up-and-down test for $1 \mathrm{~cm}$ gap distance, rod-plane, $10 \% \mathrm{C}_{3} \mathrm{~F}_{7} \mathrm{CN} /$ $90 \% \mathrm{CO}_{2}$ mixture.

resulted in having about 15-20 impulses applied to the gas before the official set of 40 impulses. A time interval of 2 minutes was applied between each impulse shot. This allowed the gas mixture to have enough time to recover after a breakdown.

The $\mathrm{U}_{50}$ was calculated using the following equation [8]:

$$
U_{50}=U_{0}+\Delta U\left(\frac{A}{k} \pm \frac{1}{2}\right)
$$

where $\mathrm{U}_{0}$ is the lowest breakdown voltage that has occurred, $\Delta \mathrm{U}$ is the step voltage, $\mathrm{A}$ is the sum of the number of events that occured at each step and $\mathrm{k}$ is the number of rarer events. If the rarer events were breakdowns, the sign would be negative, or in the case of non-breakdowns the sign would be positive.

\section{ELECTRIC FIELD COMPUTATION}

COMSOL software was used to compute the electric field distribution of the rod-plane electrode configuration with a 30 $\mathrm{mm}$ gap distance, as shown in Fig. 4. By applying the experimental breakdown data, the maximum electric field is located at the rod tip, where the breakdown is most likely to occur. In the experiment, breakdowns mostly occurred at the centre of the plane electrode, which validates the location of $\mathrm{E}_{\max }(\mathrm{kV} / \mathrm{mm})$ in the COMSOL model. Increased electric field can also be seen along the edges of the plane electrode. These edges were rounded to minimise the likelihood of breakdown occurences along the electrode edge.

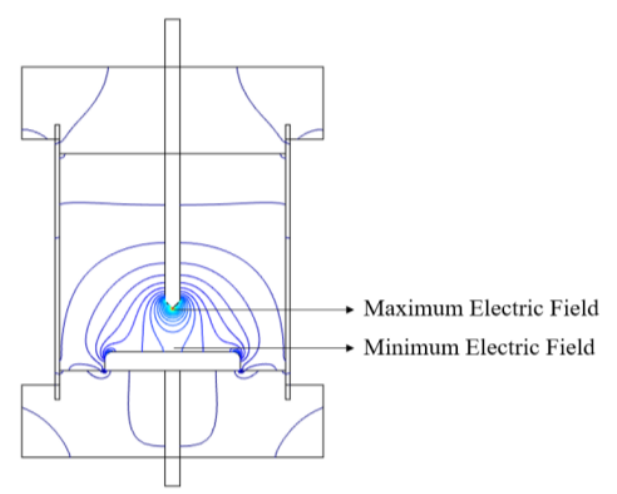

a

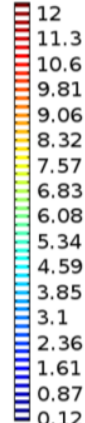

Figure 4. COMSOL simulation for $30 \mathrm{~mm}$ gap distance, rod-plane, 10\% $\mathrm{C}_{3} \mathrm{~F}_{7} \mathrm{CN} / 90 \% \mathrm{CO}_{2}$ gas mixture. 


\section{EXPERIMENTAL RESULTS AND DISCUSSION}

\section{A. Effect of Gap Distance and Mixture Ratio}

From the literature [3][9], it was found that the breakdown voltage of the gas mixture increases with $\mathrm{C}_{3} \mathrm{~F}_{7} \mathrm{CN}$ content. It can be seen from Fig. 5 that there is a small increase in the breakdown voltage of the gas when the gas changed from $100 \% \mathrm{CO}_{2}$ to a mixture of $10 \% \mathrm{C}_{3} \mathrm{~F}_{7} \mathrm{CN} / 90 \% \mathrm{CO}_{2}$. The breakdown voltage increases significantly when the concentration of $\mathrm{C}_{3} \mathrm{~F}_{7} \mathrm{CN}$ is increased to $20 \% \mathrm{C}_{3} \mathrm{~F}_{7} \mathrm{CN} / 80 \%$ $\mathrm{CO}_{2}$ mixture. The results in Fig. 5 indicate that the experimental tests of this paper are in good agreement with previous investigations [3][9].

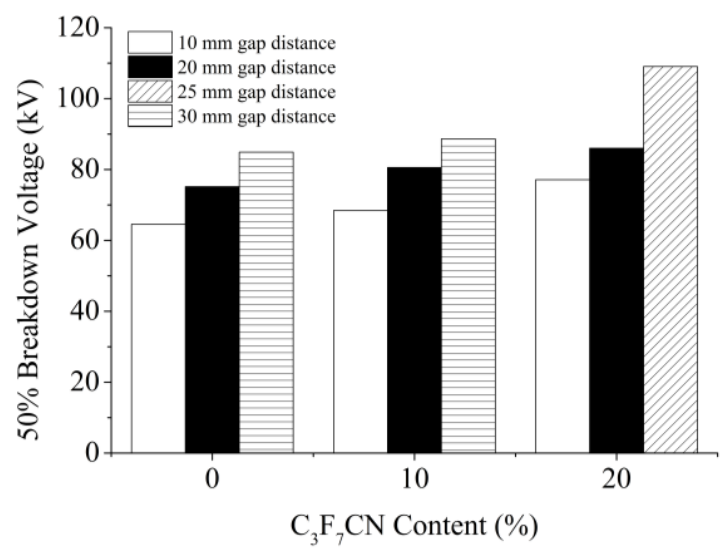

Figure 5. $\mathrm{U}_{50}$ as a function of $\mathrm{C}_{3} \mathrm{~F}_{7} \mathrm{CN}$ content in a rod-plane electrode configuration for different gap distances and positive lightning impulse.

As shown in Fig. 6, as the pressure spacing product (pd) of the gas mixtures increases so does the breakdown voltage. This agrees with Paschen's law which states that after a specific point the breakdown voltage of a gas is approximately proportional to the pressure spacing product. The mixture containing $20 \% \mathrm{C}_{3} \mathrm{~F}_{7} \mathrm{CN}$ concentration demonstrates a slightly better performance to the $\mathrm{SF}_{6}$ [5] data under positive lightning impulse and non-uniform field. It can also be seen that the rate of increase of both gases is very similar. The increased breakdown voltage of the $20 \% \mathrm{C}_{3} \mathrm{~F}_{7} \mathrm{CN} / 80 \% \mathrm{CO}_{2}$ mixture

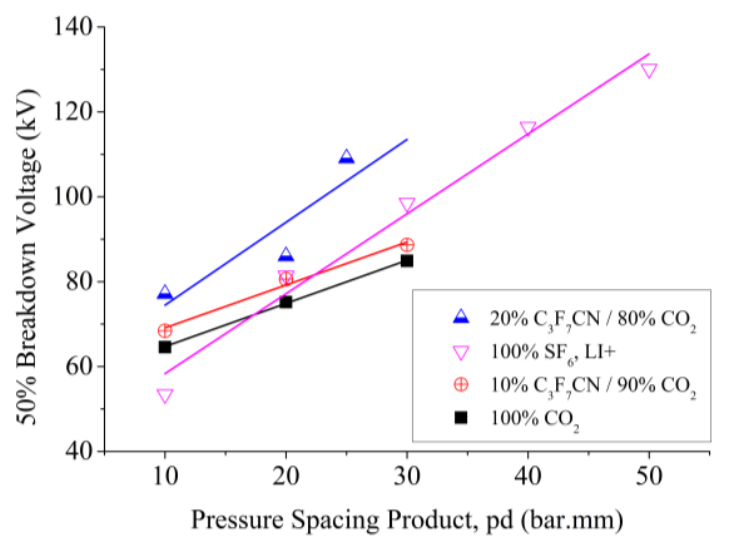

Figure 6. $\mathrm{U}_{50}$ as a function of pressure spacing product in a rod-plane electrode configuration comparing $\mathrm{C}_{3} \mathrm{~F}_{7} \mathrm{CN}$ mixtures to $\mathrm{SF}_{6}$ under positive lightning impulse. was expected as Kieffel [6] had found that a ratio of $18 \%$ to $20 \% \quad \mathrm{C}_{3} \mathrm{~F}_{7} \mathrm{CN}$ concentration could reach an equivalent breakdown voltage to $100 \% \mathrm{SF}_{6}$.

The $\mathrm{U}_{50}$ for $\mathrm{CO}_{2}$ and $\mathrm{C}_{3} \mathrm{~F}_{7} \mathrm{CN}$ gas mixtures are reasonably close at lower values of pd but the difference is more evident at higher values.

\section{B. Breakdown Field Strength}

The obtained $U_{50}$ data can be used to determine the maximum breakdown field strength $\left(E_{\max }\right)$ for each gas mixture as shown in Fig. 7. Equation (2) was developed by Howard [10] to calculate the field strength for non-uniform field electrode configurations:

$$
E_{\max }=\frac{2 U_{50}}{R \ln \left(\frac{4 x}{R}\right)}
$$

where $\mathrm{R}$ is the radius of curvature of the point tip, $\mathrm{x}$ is the rodto-plane gap spacing and $\mathrm{U}_{50}$ is the breakdown voltage.

As can be seen in Fig. 7, $E_{\max }$ decreases with increasing pd values. The breakdown field strength curves are observed to decrease more gradually at higher pd values. This requires further testing at extended pd range to verify the trend.

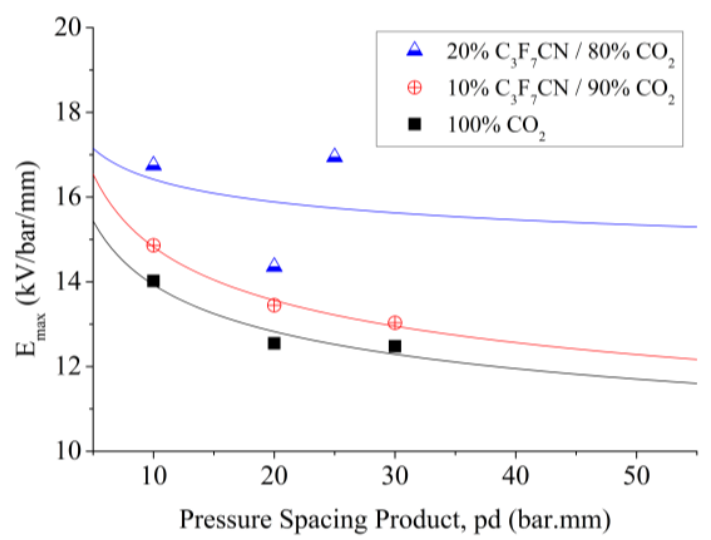

Figure 7. Breakdown field strength as a function of pressure spacing product in non-uniform gaps for different mixtures under positive lightning impulse.

\section{Voltage-time Characteristics}

V-t characteristics were also examined in this paper. The main pattern observed in Figures 8 and 9 is the $\mathrm{V}$-t curve rising gently in short time regions. One common property of all the $\mathrm{V}-\mathrm{t}$ curves shown in the two figures is that most of the breakdown times are concentrated in the region below $10 \mu \mathrm{s}$ with only a few dispersed points exceeding this value.

Fig. 8 compares the V-t characteristics for different $\mathrm{C}_{3} \mathrm{~F}_{7} \mathrm{CN}$ contents while Fig. 9 illustrates the $10 \% \mathrm{C}_{3} \mathrm{~F}_{7} \mathrm{CN} / 90 \% \mathrm{CO}_{2}$ mixture for different gap distances. Based on these results, it was found that there was little difference in average breakdown time when the $\mathrm{C}_{3} \mathrm{~F}_{7} \mathrm{CN}$ concentration was increased from $10 \%$ to $20 \%$. However, the average chopping voltage (the point where the voltage rapidly collapses to zero value during a breakdown) is increased by approximately $10 \mathrm{kV}$ when the 
mixture is changed from $10 \% \mathrm{C}_{3} \mathrm{~F}_{7} \mathrm{CN} / 90 \% \mathrm{CO}_{2}$ to $20 \%$ $\mathrm{C}_{3} \mathrm{~F}_{7} \mathrm{CN} / 80 \% \mathrm{CO}_{2}$. From Fig. 9, it can be seen that the breakdown voltage times become less dispersed as the gap distance is increased. Most of the breakdown times for the 30 $\mathrm{mm}$ gap distance are in the region below $5 \mu \mathrm{s}$. This causes the average breakdown time to reduce as the electrode gap spacing is increased. The average chopping voltage is significantly increased with longer gap spacing.

It is unclear if $\mathrm{C}_{3} \mathrm{~F}_{7} \mathrm{CN}$ concentration and electrode gap distance have a significant correlation to the $\mathrm{V}$-t characteristics based on these initial results. Further study is required to establish a clearer correlation.

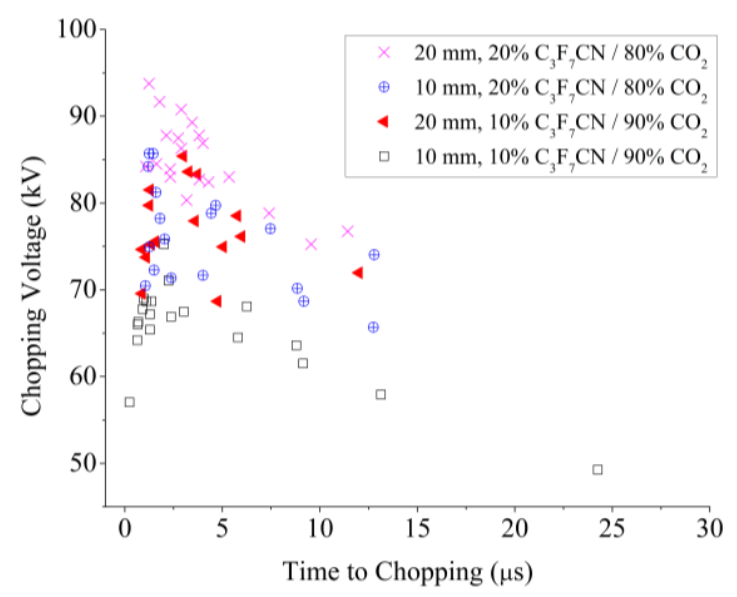

Figure 8. V-t characteristics of $\mathrm{C}_{3} \mathrm{~F}_{7} \mathrm{CN}$ mixtures under positive lightning impulse.

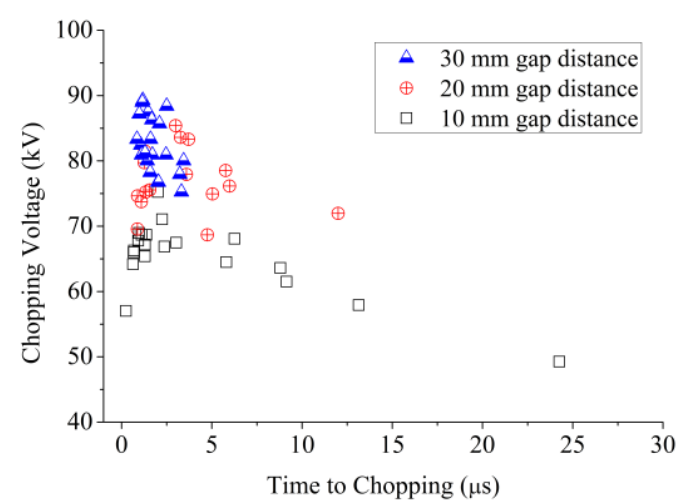

Figure 9. V-t characteristics of $10 \% \mathrm{C}_{3} \mathrm{~F}_{7} \mathrm{CN} / 90 \% \mathrm{CO}_{2}$ for different gap distances.

\section{CONCLUSION}

This work presents the experimental investigations carried out on $\mathrm{C}_{3} \mathrm{~F}_{7} \mathrm{CN} / \mathrm{CO}_{2}$ mixtures as a potential alternative to $\mathrm{SF}_{6}$ in high voltage equipment. Experiments were conducted using a rod-plane electrode configuration with varying conditions such as gap spacing and mixture ratio. All the experiments were carried out using standard lightning impulse voltage $(1.2 / 50 \mu \mathrm{s})$ of positive polarity. Initial results have shown that increased $\mathrm{C}_{3} \mathrm{~F}_{7} \mathrm{CN}$ concentration and gap spacing can increase the breakdown voltage of the gas mixture. The mixture of $20 \%$ $\mathrm{C}_{3} \mathrm{~F}_{7} \mathrm{CN} / 80 \% \mathrm{CO}_{2}$ proved to have a higher breakdown voltage compared to $100 \% \mathrm{CO}_{2}$ and $10 \% \mathrm{C}_{3} \mathrm{~F}_{7} \mathrm{CN} / 90 \% \mathrm{CO}_{2}$. The same mixture has shown higher breakdown performance than $\mathrm{SF}_{6}$ under non-uniform field and positive LI. This, however, was not a direct comparison since the $\mathrm{SF}_{6}$ data was extracted from the literature. Further testing is necessary in the future to investigate $\mathrm{C}_{3} \mathrm{~F}_{7} \mathrm{CN}$ and the effect that conditions such as field uniformity and pressure have on the dielectric strength of the gas. Results in this paper have shown that $\mathrm{C}_{3} \mathrm{~F}_{7} \mathrm{CN}$ can be a promising candidate to replace $\mathrm{SF}_{6}$ gas in high voltage applications.

\section{ACKNOWLEDGEMENT}

This work was supported in part by a Ph.D. studentship from the Engineering and Physical Sciences Research Council (EPSRC), Industrial Cooperative Awards in Science \& Technology, and in part by National Grid, UK.

\section{REFERENCES}

[1] Y. Kieffel, T. Irwin, P. Ponchon, and J. Owens, "Green Gas to Replace SF6 in Electrical Grids," IEEE Power Energy Mag., pp. 32-39, 2016.

[2] IPCC, "Climate Change 2013: The Physical Science Basis. Working Group I Contribution to the Fifth Assessment Report on Interngovernmental Panel on Climate Change," 2013.

[3] J. G. Owens, "Greenhouse Gas Emission Reductions through use of a Sustainable Alternative to SF6," in IEEE Electrical Insulation Conference (EIC), 2016, pp. 535-538.

[4] M. Hyrenbach and S. Zache, "Alternative insulation gas for medium-voltage switchgear," Pet. Chem. Ind. Conf. Eur. Conf. Proceedings, PCIC Eur., 2016.

[5] E. Kuffel and A. Yializis, "Impulse Breakdown of Positive and Negative Rod-Plane Gaps in SF6-N2 Mixtures," IEEE Trans. Power Appar. Syst., vol. PAS-97, no. 6, pp. 23592366, 1978.

[6] Y. Kieffel, "Characteristics of g3 - An alternative to SF6," in 2016 International Conference on Dielectrics (ICD), 2016, pp. 880-884.

"BS EN 60060-1:2010: High-Voltage test techniques, Part 1: General Definitions and test requirements," Br. Stand. Institutions, 2010.

[8] W. Hauschild and W. Mosch, Statistical Tecnhiques for High-voltage Engineering. 1992.

[9] H. E. Nechmi, A. Beroual, A. Girodet, and P. Vinson, "Fluoronitriles/CO2 gas mixture as promising substitute to SF6 for insulation in high voltage applications," IEEE Trans. Dielectr. Electr. Insul., vol. 23, no. 5, pp. 2587-2593, 2016.

[10] P. R. Howard, "Process contributing to the breakdown of electronegative gases in uniform and non-uniform electric fields," Proc. IEE - Part A Power Eng., no. 2260, pp. 139$142,1957$. 